$\begin{array}{ll}\begin{array}{ll}\text { Australian Journal of } \\ \text { Crop Science }\end{array} & \text { A JCS } \\ \text { AJCS 15(08):1119-1129 (2021) } & \text { ISSN:1835-2707 }\end{array}$

doi: 10.21475/ajcs.21.15.08.p3082

\title{
Either embryogenesis or indirect organogenesis in sugarcane: Are we missing the key points?
}

\author{
Manoel Viana Linhares-Neto ${ }^{1}$, Letícia Rios Vieira ${ }^{1}$, Pedro Vitor Schumacher ${ }^{1}$, Mariele Rossato ${ }^{1}$, Luciano \\ Coutinho Silva ${ }^{2}$, Fabrício Jose Pereira ${ }^{3}$, Renato Paiva ${ }^{1}$, Antonio Chalfun-Junior ${ }^{{ }^{*}}$
}

${ }^{1}$ Department of Biology, Plant Physiology Sector, Federal University of Lavras, Brazil

${ }^{2}$ Department of Cellular and Molecular Biology, CBIOTEC, Federal University of Paraíba, Brazil

${ }^{3}$ Department of Biology, Institute of Natural Sciences, Federal University of Alfenas, Brazil

\author{
*Corresponding author: chalfunjunior@ufla.br \\ (ORCID: 0000-0002 - 1794-9429)
}

\begin{abstract}
Both in vitro establishment and callogenesis of sugarcane allow a production of quality regenerative material, which is necessary for in vitro clonal propagation and for genetic transformation. In this study, we establish the efficient production of calli from the RB855156, RB92579 and RB867515 cultivars and characterize their regenerative potential in relation to either an embryogenic or an organogenic origin both by morphology and by anatomy. Callogenesis was induced in MS medium with $3.0 \mathrm{mg} \mathrm{L}^{-1} 2.4-\mathrm{D}$. Three antioxidants were tested: polyvinylpyrrolidone $\left(150 ; 300 ; 600 \mathrm{mg} \mathrm{L}^{-1}\right)$, citric acid $\left(7.5 ; 15 ; 30 ; 60 \mathrm{mg} \mathrm{L}^{-1}\right)$, and ascorbic acid $(7.5 ; 15$; $\left.30 ; 60 \mathrm{mg} \mathrm{L}^{-1}\right)$. The morphological characterization of the calli was performed by visual classification, and the anatomical analyses by light microscopy. The experimental design was completely randomized, containing 150 explants by cultivar to antioxidant evaluations and potential regenerative evaluation within three times of subcultures $(84 ; 112 ; 140$ days). We have attained the key points of our in vitro research. Calli regeneration depended on the oxidation level and genotype. Antioxidants only in the culture medium were not enough to prevent oxidation. However, citric acid $\left(7.5 \mathrm{mg} \mathrm{L}^{-1}\right)$ as a pretreatment of the explant minimized this problem. Bacterial contamination was developed for the three cultivars, inhibiting the establishment to RB867515. The disinfestation protocol was efficient for RB855156 and for RB92579 cultivars. Three varieties of calli differed in the regeneration potential. In addition, histological analysis of the calli unfolded not only that there were structural differences but also that their buds had an organogenic origin.
\end{abstract}

Key words: Saccharum spp.; Tissue Culture; Morphoanatomical Characterization; Genetic Transformation. Abbreviations: FAA: formaldehyde, acetic acid and 70\% alcohol. GIMP: GNU Image Manipulation Program. M: mucilaginous callus. MS: Culture Medium (Murashige and Skoog, 1962), containing macronutrients, micronutrients and vitamins.

NW: compact nodular white callus. PVP: polyvinylpyrrolidone.TF: translucent friable callus.

Introduction

Most varieties of sugarcane have been prevailed by classical plant breeding (Andrade et al., 2011; Silva and Gonçalves 2011; Carvalho and Furtado, 2013). However, the limitations of this approach have fostered the development of new genetic breeding techniques. Genetic transformation is an option for generating plants with phenotypes that are not acquired by conventional breeding (Birch 1997; Mancini et al., 2017). Therefore, regenerative calli, either embryogenic or organogenic, are sought for this approach.

The most commonly used material for sugarcane genetic transformation is an embryogenic callus, which is obtained from immature leaves. For example, sugarcane callogenesis is achieved from the immature leaves of the shoot apex that surround meristematic tissue (Santosa et al., 2004). Besides, it can be referred to as "palm-heart" (Mudry et al., 2013). Embryogenic callus formation in sugarcane varieties is mostly obtained on Murashige and Skoog (MS) medium
(Murashige and Skoog 1962) supplemented with 2,4-D (2,4dichlorophen-oxyacetic acid) at concentrations ranging from 2.0 to $4.0 \mathrm{mg} \mathrm{L}^{-1}$ (Attia et al., 2005; Dibax et al., 2013; Mudry et al., 2013; Soares et al., 2014). Although this protocol is commonly reported to obtain embryogenic calli, there are few studies on histology using this sugarcane material to attest whether this is a case of either embryogenesis or organogenesis. There are also core problems related to in vitro cultivation of several species, which are not only the contamination of the material but also the oxidation of it. Both cause growth inhibition and the death of a large number of explants (Melo et al., 2001; Bassan et al., 2006; North et al., 2010; Palú et al., 2011a; Reddy et al., 2015; Orlikowska et al., 2017). Hence, there are practices usually adopted to minimize some effects i.e. the plant material should be washed under running water before any other procedure such as: (i) disinfestation, (ii) administration of 
antioxidants, (iii) reduction of mechanical and chemical injuries to explants, (iv) reduction of laminar air flow chamber luminosity, and $(v)$ initial dark incubation (Cidade et al., 2006; Dibax et al., 2013; Sartor et al., 2013). Nevertheless, these practices are not always effective to in vitro establishment and to plant regeneration.

In vitro plant regeneration can be fulfilled: either through somatic embryogenesis or through organogenesis. In these cases, phytohormones induce cell division, dedifferentiation, the acquisition of embryogenic/organogenic competence and the initiation and development (De Klerk et al., 1997; Dhaliwal et al., 2003; Duclercq et al., 2011). Both organogenesis and somatic embryogenesis are exploited extensively (Davey and Anthony, 2010). Being a major target of in vitro propagation and genetic engineering, especially in dicotyledons, organogenesis maintains both environmental conditions and explant robustness (Duclercq et al., 2011). However, a central issue still remains, and through this investigation we respond these following research questions: (i) is the material origin regenerated either by embryogenesis or by organogenesis? (ii) What is the appropriate regulator used? And what is its concentration? Therefore, the aim of this study is not only to quantify the efficiency of protocols for disinfestation, oxidation control, determination of the regenerative potential but also to elucidate the origin of the embryogenic/organogenic sugarcane calli by morphological and by histological characterization.

\section{Results}

\section{In vitro establishment}

The results of the present study unfolded that the sugarcane cultivars (RB855156, RB92579 and RB867515) evidenced differences in vitro establishment. Although the occurrence count on microbial contamination varied as a function of both genotype and time, the differences were not significant. Visual analysis indicates the growth of four different types of bacteria; however, explants of the same shoot apex present contamination with only one (Supplementary Fig. 1).

Bacterial contamination occurred in all three cultivars, though it did not affect in vitro establishment of both RB855156 and RB92579 cultivars (Figure 1A). The high contamination rate, observed in the RB867515 variety on the seventh day after establishment, prevented in vitro cultivation when, at 14 days of cultivation, all explants were visually contaminated. There was a low rate of fungal contamination in the explants of the three cultivars, not exceeding 3\% (Figure 1B).

\section{Pretreatment with antioxidant solution}

Pretreatment with antioxidant solution prevented instant oxidation caused by explant excision. According to the results, the explant inoculation step revealed to be critical to the sugarcane. The explant became oxidized at the time of cutting, even before being inoculated into the culture medium (Supplementary Fig. 2A). Explants that were cut with a scalpel wetted on $500 \mathrm{ppm}$ PVP solution, as well as bathing on the same PVP (solution/concentration) did not undergo oxidation at the time of inoculation (Supplementary Fig. 2B). During the four weeks of cultivation, the pattern of different levels of oxidation was evaluated, which increased the reliability of visual analysis (Supplementary Fig. 3). In addition, the use 2,4-D in the concentration of $3.0 \mathrm{mg} \mathrm{L}^{-1}$ promoted inducing callogenesis in the studied cultivars.
The highest levels of non-oxidized explants developed in the first week in all cultivars. However, over the weeks, they became increasingly oxidized. Due to the high bacterial contamination in RB867515 cultivar, the data were more informative in both RB855156 and RB92579 cultivars. The results proved that there was no interaction of time on oxidation levels, and that explants were unviable in each cultivar. Thus, the results of oxidation and explants unviability were analyzed for each week of evaluation individually (Figure 2).

The data were derived through the percentage of nonoxidized explants, slightly oxidized explants and totally oxidized ones beyond the non-viable explants (dead due to contamination level). The highest percentages of nonoxidized explants in the cultivars arose in the first week, compared to the levels of both oxidation and non-viable explants (Figure 2A). In the second week, an intermediate level of oxidation and non-viable explants accumulated for RB855156 cultivar, in contrast to RB92579 cultivar, where oxidation levels were similar; however, still between cultivars, RB855156 cultivar presented more non-oxidized explants (Figure 2B). In the third and fourth week, the results had no significant differences between the two cultivars for both the oxidation levels and non-viable explants. However, in RB855156 cultivar, a higher percentage of non-viable explants (eliminated by contamination) than totally oxidized explants still prevailed (Figure 2C and 2D).

\section{Oxidation level in the explants}

Explants, taken from the shoot apex base, led to less oxidation. Throughout the period of in vitro cultivation, explant oxidation caused undesirable material losses in all cultivars. A linear increase in relation to the position of the explant in the shoot apex and the oxidation was perceived (Supplementary Fig. 4). The lowest levels of oxidation emerged both at the base of the shoot apex and at the intensity of it in the most apical region (Figure 3).

\section{Antioxidants efficiency}

Citric acid has shown the most efficient antioxidant function (Figure 4). The lowest oxidation rates were monitored in the citric acid treatments in concentrations of $7.5 \mathrm{mg} \mathrm{L}^{-1}$ and 60 $\mathrm{mg} \mathrm{L}^{-1}$. On the other hand, ascorbic acid was less effective than citric acid, and it was still with lower oxidation than in the control treatment. However, regardless of the PVP concentration, this treatment resulted in higher oxidation levels, which were even higher than in the control treatment.

\section{Calli morphological aspects}

Both the RB855156 and RB92579 cultivars have exhibited three types of calli showing the same morphological and developmental pattern. In the third subculture (on the eighty-fourth day), the different callus types could be properly separated and identified as compact nodular white (NW), translucent friable (TF) or mucilaginous (M) (Supplementary Fig. 5).

The nodular calli conveyed whitish, small and dry-looking cells, and they formed compact nodules that detached easily from the explants (Supplementary Fig. 5A). The translucent friable calli were transparent, yellowish and dry in appearance, and their cells were relatively large and friable (Supplementary Fig. 5B). The mucilaginous calli indicated a homogeneous wet, viscous and grayish-colored mass (Supplementary Fig. 5C). 


\section{Regenerative potential of the calli}

The callus regenerative potential decreased sharply across subcultures. At the end of the first subculture ( 56 days after inoculation), there was not enough morphological differentiation of the different callus types to be distinguished. On the 84th day after inoculation (end of R2), the highest regeneration percentage was noticed. In the TFtype, the callus regeneration rate was also high $(90 \%$ of events with shoots); however, the M-type did not demonstrate regeneration. On the 112 nd day (R3), both NW and TF calli exposed a sharp drop in the regeneration rate (35\% and $30 \%$ regeneration events, respectively). On the 140th day (R4), the regeneration events ceased (Supplementary Table 1).

\section{Structural analyses among the calli types}

NW, TF and $M$ calli evidenced differences in tissue organization, cell types, callus nutrition, adhesion to explants and ontogenesis (Figure 5).

Callus-type NW was globular, carrying a base with a bottleneck shape that uncovered itself connected directly with the explants' xylem (Figure 5A and 5D). NW callus margins were defined by a well-organized protoderm composed of tabular cells (Figure 5G). In the central part of the calli, there were meristematic cells with large nuclei in relation to the cytoplasm, indicating potential for cell division (Figure 5J). The procambium region was located above the meristematic region, and its cells proclaimed a large nucleus in relation to the cytoplasm. This region was darker and expressed a cell cluster that indicated a high rate of cell division. Above the procambium, there was also a protoderm delimiting the apex of NW calli, which differed from that found in other callus types (Figure $5 \mathrm{~J}$ ).

The TF calli also had a globular shape with little organized protoderm (Figure $5 \mathrm{~B}$ and $5 \mathrm{H}$ ). The calli were connected directly to the explant epidermis, and their cells were elongated. However, they were shorter than those of NW the NW's ones (Figure $5 \mathrm{E}$ ). The procambium region was located at the top of the callus and it showed less cell agglomeration compared to the NW procambium. There was no protoderm in the apical part of the TF callus (Figure 5K).

Callus type $M$ had an oval structure with units very close to each other, which defined the nonfriable appearance of this callus (Figure $5 \mathrm{C}$ ). Not only this proximity but also the lack of a protoderm in the structures resulted in the absence of defined delimitation (Figure 5I). The base was directly linked to the explant epidermis, although there were no elongated cells (Figure 5F). We may notice a region of procambium with large numbers of cells both with large and very evident nuclei. However, the apex cells not only divided but also gave rise to elongated cylindrical cells that detached from the callus and that formed a mucilaginous mass (Figure 5I).

\section{Regenerated shoots}

The histological analysis, carried out throughout the development, revealed that the shoots regenerated from RB92579 cultivar calli had organogenic origin (Figure 6). The formation of meristematic regions in regenerable calli may be observed even before subjecting them to regeneration conditions (Figure 6A). Thus, the meristematic point was completely enveloped by the callogenic mass, suggesting its origin (Figure 6B). Besides, the xylem was another indication that the callus was nourishing this meristematic point (Figure 6A and B). In detail, the Figure $6 \mathrm{c}$ implied A tunic composed of two layers of cells with anticline divisions and a body below the tunic with three layers of cells with periclinal division, which characterize the apical meristem. The shoots indicated leaf primordia with a protoderm and fundamental meristem after seven days of light exposure (Figure 6D). The figure $6 \mathrm{E}$ detailed the bud development through procambium cells fundamental meristem and xylem cells of the callogenic mass, which delimited the growth of this bud through procambium cells. With the development of the shoots, other leaf primordia were alternately arranged, as expected for the species (Figure 6F).

\section{Discussion}

Bacterial contamination did not prevent in vitro establishment of the cultivars, except for the RB867515 cultivar.

The control of in vitro contamination is one of the basic requirements for an efficient tissue culture technology. To understand the source of contamination, we investigated supposed relations about micropropagation in sugarcane and in contamination origin. Endogenous contamination occurrences are common in sugarcane cultivars (Zami et al., 2014; Garcia et al., 2019). The contamination of the shoot apex explants of both RB855156 and RB92579 cultivars could be of epiphyte origin. This result unfolds that disinfestation has not been completely efficient, either for the total bacterial elimination or for endogenous inhabited only in a part of the plant (Leifert et al., 1991).

Endogenous contaminations, specialties by bacteria, may be beneficial for in vitro cultivation (Jimtha et al., 2014; Orlikowska et al., 2017). However, in the sugarcane cultivars used in this study, contamination was not beneficial to the explants since as they present both intense oxidation and subsequent death. Regarding fungi, the low contamination rate (in the explants of the three cultivars) unveiled that epiphytes fungal were eliminated by simple disinfection, using ethanol $70 \%$ and sodium hypochlorite (Leifert et al., 1991; Palú et al., 2011b). Systemic contamination produced by endogenous pathogens in sugarcane had difficult control as long as it was not affected by superficial sterilization (Lal et al., 2014). Hence, we encourage the use of either some antibiotics in the culture medium (Palú et al., 2011b) or in vitro plant explants from contaminants-free (Leifert et al., 1991).

\section{Pretreatment with antioxidant solution prevents instant} oxidation caused by explant excision.

The explant oxidation, in this inoculation step, is highly crucial and prejudicial to in vitro establishment of the plant material. The contaminated explants have been discarded and classified as dead explants. Owing to the endogenous contamination of the RB867515 cultivar, the oxidation evaluation was impaired, as explant contamination is a factor that can induce increased oxidation. (Brondani, 2003; Houllou and Souza, 2015). The material oxidation became progressive in the first week, $42 \%$ of the explants were contaminated reaching $82 \%$ at the endpoint. In several species, oxidation was reported to be detrimental to in vitro development of plant materials when targeting micropropagation (Mudry et al., 2013; Bassan et al., 2006; Camolesi et al., 2007). We evidence that other sugarcane studies also indicate a large loss of material due to this problem (Mudry et al., 2013; Houllou and Souza, 2015; Nogueira et al., 2019), which hinders large-scale callus production.

Disregarding contaminated explants showing high oxidation, the callus formation existed in $100 \%$ of the inoculated 
explants of the two remaining cultivars. This result demonstrated a prevalence of RB855156 and RB92579 cultivars over aspects of both contamination and oxidation. Callogenesis efficiency was assessed in other sugarcane cultivars (Jahangir et al., 2010; Van Der Vyver et al., 2013; Alcantara et al., 2014). This efficiency in our study was due to the response between genotypes and the used 2,4-D. Therefore, the concentration of $3.0 \mathrm{mg} \mathrm{L}^{-1}$ was efficient in inducing callogenesis in the studied cultivars, requiring only attention and adjustments related to the oxidation of plant material throughout the culture time and genotype utilized.

\section{Explants obtained from the shoot apex base presented less oxidation}

The farther the explant distance from the apical meristem stands, the lower the percentage of embryogenic callus formation is (Ho and Vasil, 1983). The loss of the embryogenic callus formation capacity requires attention to both an increase in oxidation and a decrease in the cell's dedifferentiation capacity (Nagata, 1994). Younger tissues also pose high production of auxin, which induces callus formation at high concentrations (Werner et al., 2009). Consequently, the explants closest to the apical meristem should preferably be used.

\section{Citric acid has unveiled the most efficient antioxidant function}

Citric acid has disclosed prolong performance since it may have regulated oxidation by lowering the $\mathrm{pH}$ and inactivating oxidizing enzymes (He and Luo, 2007). Both PVP and ascorbic acid revealed more restricted action, depending on the proportions of both the active enzymes and the available substrate (Borneman et al., 2001; He and Luo, 2007). When the amount of substrate (PVP or ascorbic acid) available for enzyme inactivation was not sufficient, the oxidation level increased. The best performance of citric acid can be to the relationship between its mode of action and the explant residence time in the culture medium, where the callus induction period of sugarcane explants is long, continuing for more than 20 days in the culture medium before a change is detected. It is relevant to consider the optimization of antioxidant treatment in vitro establishment based on genotypes, identifying the most appropriate explant physiological stage development to provide the rate of viable better explants.

\section{Different types of calli identified are morphologically identical both in RB855156 and RB92579 cultivars.}

The morphological characterization of calli unfolded in a morphologic standard, but some differences still persisted in color due to the use of different cultivars. We considered either nodular or friable calli such as embryogenic and regenerable. In addition, mucilaginous calli were described as nonregenerable and therefore should be eliminated during subculture (Malabadi et al., 2011; Dibax et al., 2013; Smith et al., 2014). The increase in mucilaginous callus volume was greater than the increase in volume for the other calli. Normally, mucilaginous calli were found at the explant edge, where the oxidation level was higher. Very oxidized explants were unlikely to expose calli, but when calli lies, they were mucilaginous. Mucilaginous callus growth may reduce the growth rates of other callus types in the same explant. The more a callus grows, the more water, nutrients and regulators of the culture medium it consumes (Ramage and Williams, 2002; Niedz and Evens, 2007; Appezato-da-Glória and Hayashi, 2012). Thus, whereas the oxidation level decreased, the appearance of mucilaginous calli also mitigated. We believed that the availability of nutrients could increase, leading to an increasing growth of both NW- and TF-type calli.

\section{Callus regenerative potential decreases sharply across subcultures}

All NW callus started regeneration events and consequently shoots were formed (Supplementary Fig. 6A). Some greening was observed on the TF-type (Supplementary Fig. 6B) and the M-type calli did not develop any condition of budding or greening in any of the subcultures (Supplementary Fig. 6C). The M-type calli showed no regenerative potential, which can be recurrent (Basnayake et al., 2011; Mudry et al., 2013; Alcantara et al., 2014).

The results demonstrated that callus age was a critical factor in the success of its regeneration. The findings of an ideal concentration of a growth regulator for better regenerate calli in sugarcane is a critical stage (Raza et al., 2012; Dibax et al., 2013; Nawaz et al., 2014). Although the use of 2,4-D (3 $\mathrm{mg} \mathrm{L-}{ }^{1}$ ) is well described to produce embryogenic calli in sugarcane (Jahangir et al., 2010; Van Der Vyver et al., 2013; Soares et al., 2014) with regeneration potential (Basnayake et al., 2011; Raza et al., 2012; Nawaz et al., 2014), the calli obtained in the present study seem to be not embryogenic. The concentration of 2,4-D was a factor influenceable in both morphological aspect and callus regeneration. In sugarcane, lower concentrations of 2,4-D (1.0 and $1.5 \mathrm{mg} \mathrm{L}^{-1}$ ) may promote purple somatic embryos in the bud explants, whereas higher concentrations $\left(<4.0 \mathrm{mg} \mathrm{L}^{-1}\right)$ may induce non-embryogenic callus of yellowish color (Zamir et al., 2014). Moreover, few studies regard the structural aspects of the embryogenic callus morphology and histology in sugarcane as well as the histological changes linked to regenerative cell activity. These are the basic requirements in the study of somatic embryogenesis (Maciel et al., 2010).

\section{Histological differences among the calli type indicate a relationship to the callus regeneration potential.}

Comparing the anatomic results, there is a relationship between the histological structure and the callus regeneration. The complexity of the callus tissue organization is directly linked to its regenerative potential. Therefore, the higher the level of the organization and the structure is, the greater the regenerative potential, revealing its correlation. Moreover, we also prove that those calli are organogenic although they are proposed as embryogenic calli in sugarcane achieved by the use of $3 \mathrm{mg} \mathrm{L}^{-1}$ 2,4-D (Jahangir et al., 2010; Van Der Vyver et al., 2013; Soares et al., 2014). The connections by elongated cells may uncover a transfer function to the NW calli. Hence, this result implies that NW callus derives from nutrition more efficiently due to the greater possibility of nutrient absorption from the medium. The TF-calli showed few evident protoderms and was directly connected to the explant epidermis although they were shorter than those of NW. The cells located in the central part of the callus have a smaller nucleus concerning the cytoplasm, and their meristematic potential is lower than the equivalent in NW. Callus type $M$ central part has both oval cells with a large cytoplasm and small and unclear nuclei, which discloses its meristematic characteristics into question (Schiavone and Cooke, 1985; Quiroz-Figueroa et al., 2006).

In sugarcane, there are cell characteristics such as cylindrical, elongated and unconnected ones highlighted in the nonregenerable calli, which defines independent 

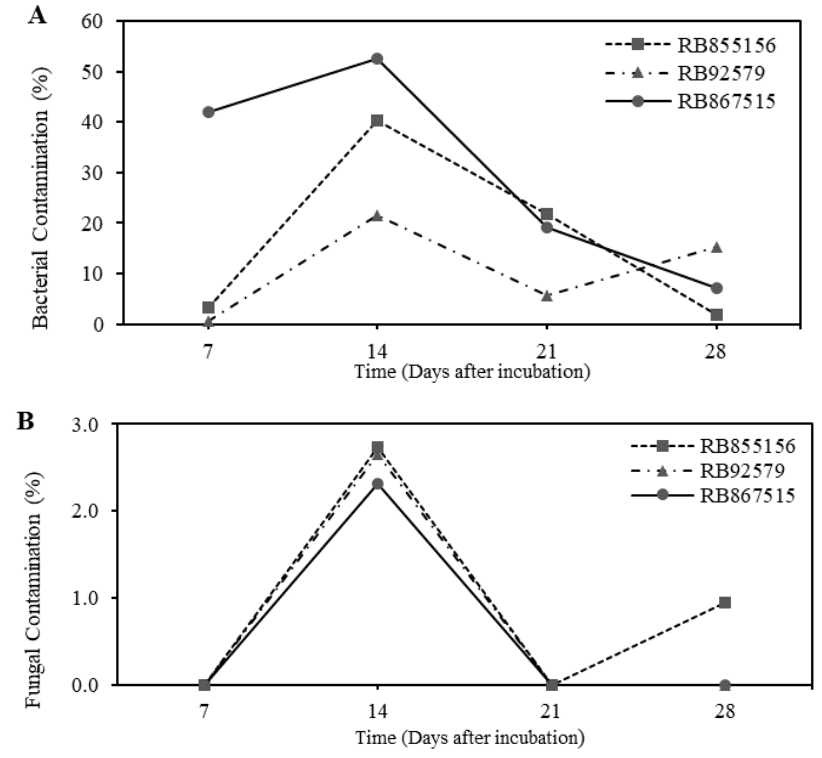

Fig. 1. The microbial contamination percentage on in vitro establishment of the sugarcane explants. Bacterial percentage (A) and fungal (B) contamination in the cultivars (RB855156; RB92579; RB86751). Each row represents a total cottage of the explant numbers from the shoot apex of each cultivar, indicating the quantity in each time (week). The data were generated over 28 days after incubation, highlighting the high bacterial contamination intensity compared with fungal contamination among cultivars.

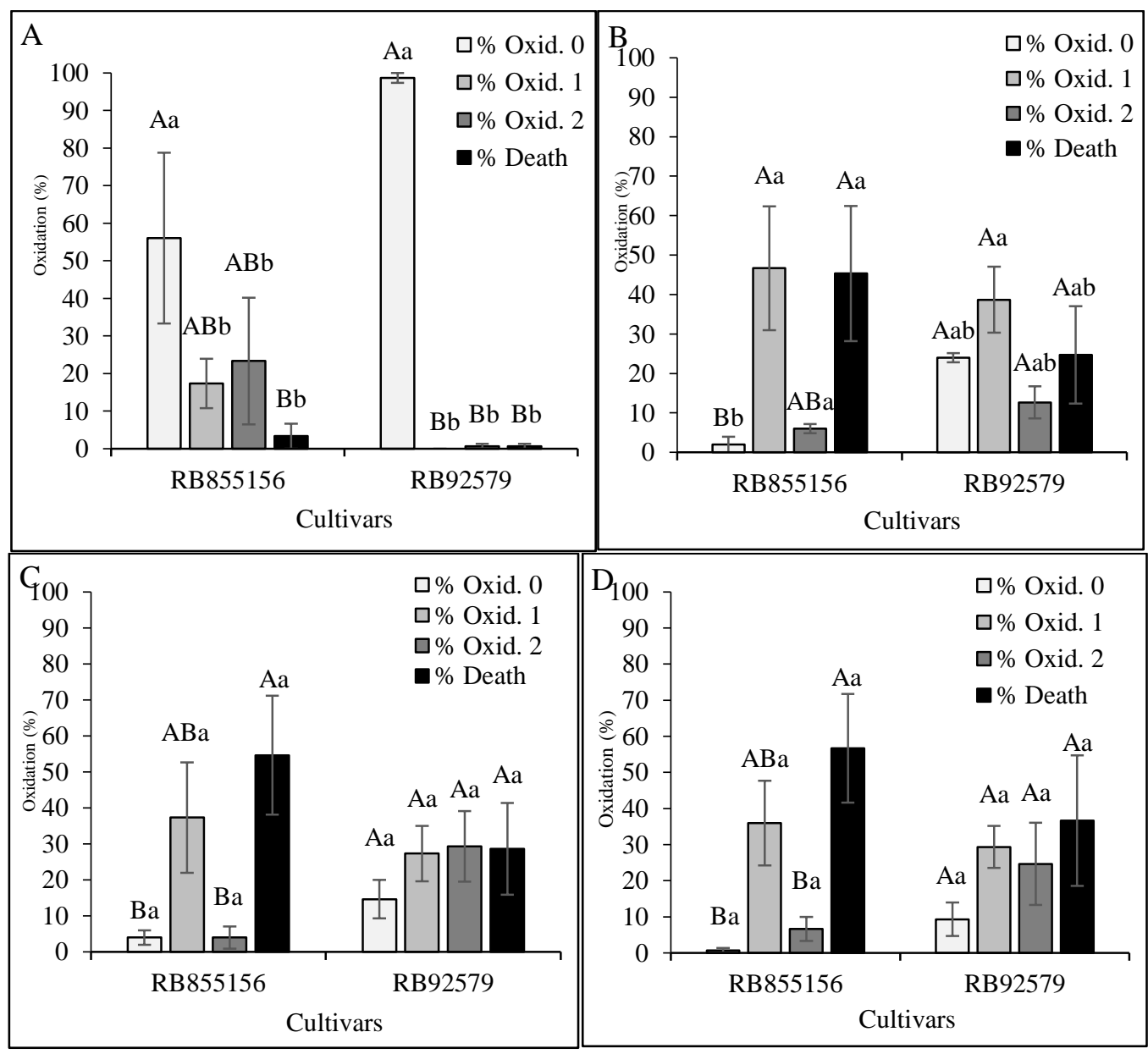

Fig. 2. Explants oxidation of the RB855156 and RB92579 cultivars throughout the 1st (A), 2nd (B), 3rd (C) and 4th (D) evaluation weeks. The explants oxidation intensity is at four levels. The grade attributed is represented from 0 to 2 : \% Oxid. 0; \% Oxid. 1; \% Oxid. 2; Dead = unfeasible. A general percentage for all explants using a classification (grade) of the oxidation level, based on qualitative visual analysis. The data were submitted to variance analysis and means compared by the Tukey's test $(p<0.05)$. Uppercase letters indicate a significant difference among the oxidation levels in each cultivar; lowercase letters indicate a significant difference between cultivars. The interval bars represent the sample standard error. 


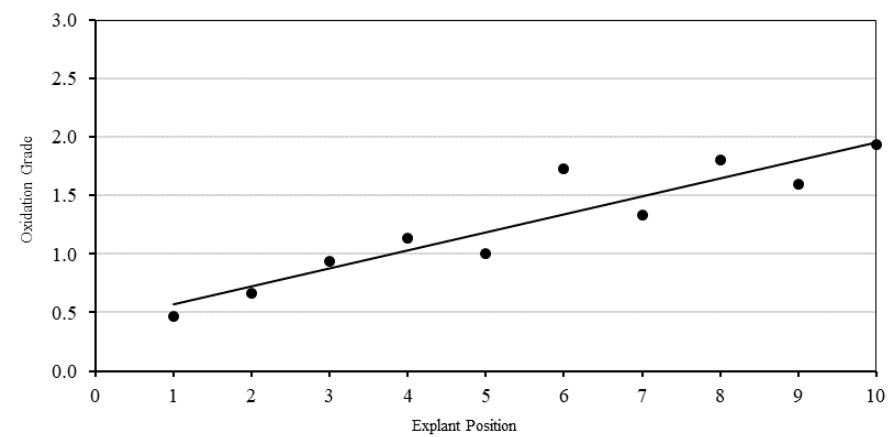

Fig. 3. Oxidation along the shoot apex according to the explant position (RB92579 cultivar). The explant position was numbered from 1 to 10 from the shoot apex meristem base to its apex, which upper region of the stalk known as "palm-heart" containing the meristematic tissue and covered by immature leaves. The crescent oxidation in the shoot apex explant is observed $\left(R^{2}=0,86\right)$. In highlight, the closer to the apical meristem, the better the quality of the material. The $y$-axis indicates the average of the score for the oxidation occurrence.

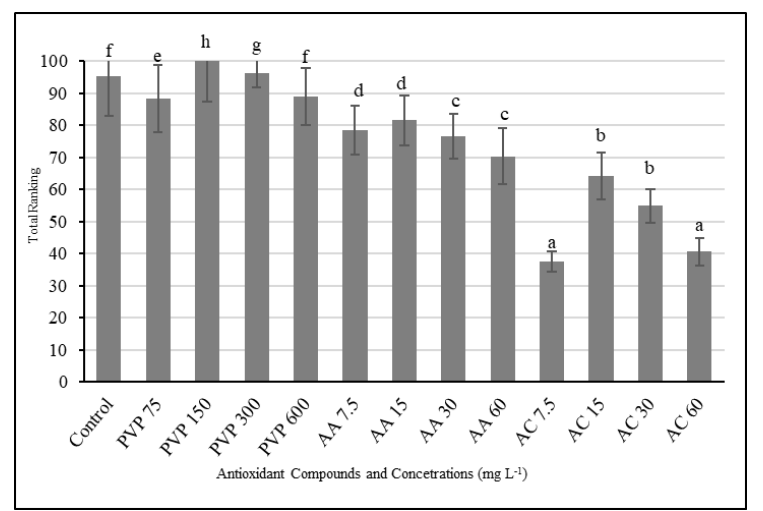

Fig. 4. Rank sums (Kruskal-Wallis) for oxidation notes according to the use of antioxidants (AA - ascorbic acid and its concentrations ( $m g L^{-1}$ ), $A C$ citric acid and its concentrations $\left(\mathrm{mg} \mathrm{L}^{-1}\right)$ ). The rank sums followed by the same letter in each column do not statistically differ $(p \leq 0.05)$; the data are presented as a percentage based on the tanks; the interval bars indicate the standard error.

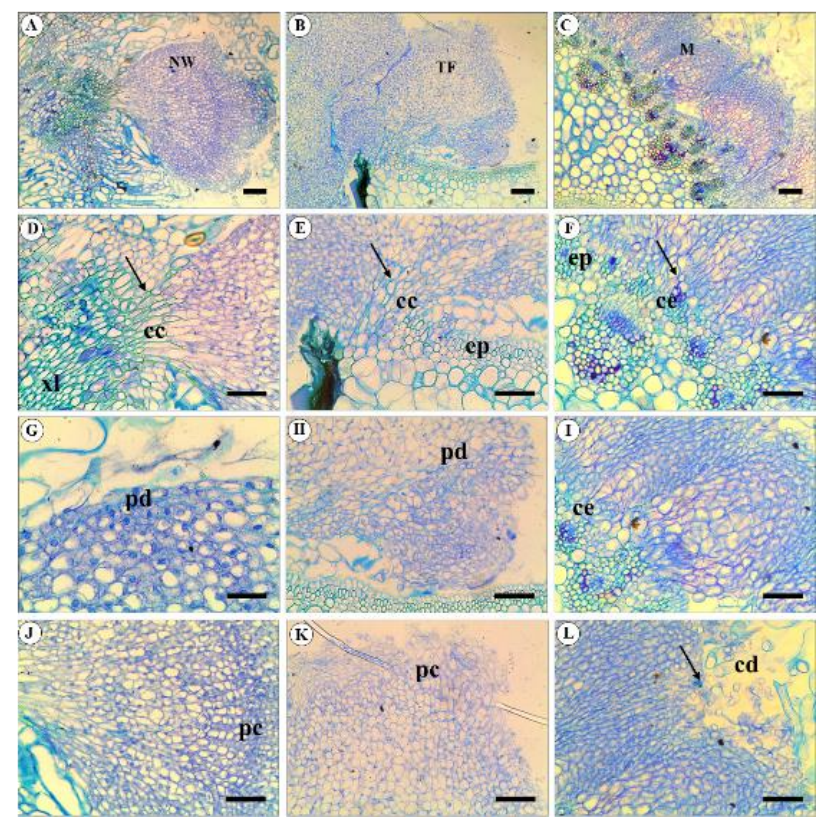

Fig. 5. Light micrograph from sugarcane calli (cultivar RB92579). Structural differences among compact-nodular-white (NW), translucent-friable (TF), and mucilaginous (M) calli (A, B, C, respectively) of the RB92579 cultivar about the explant connection (D, E, F), protoderm (G, H, I), procambium, and callogenic apex $(\mathrm{J}, \mathrm{K}, \mathrm{L})$. The NW calli (A) exhibit a base connected directly with the explant's xylem (arrow) suggesting a possible transfer function (D), and its margins (pd) are composed of tabular cells $(G)$, whereas the meristematic central region suggests cell division potential (J). Above the procambium ( $\mathrm{pc}$ ) there is a protoderm delimiting the apex of the callus, differently from the other callus types. The TF calli (B) exhibit little organized protoderm ( $\mathrm{B}$ and $\mathrm{H}$ ). They have a connection direct to the explant epidermis (arrow), exhibiting smaller cells compared to those of NW (E). The central cells have a reduced size nucleus (suggesting lower meristematic potential than the equivalent in NW), whit procambium to the apex, and without protoderm (K). The M calli are oval (C) where the lack of a protoderm resulted in undefined delimitation (I). Its base is directly linked to the explant epidermis (arrow) without elongated cells, whereas the central region has no similar to meristematic cells (F). The apex cells besides divide as well give rise to cells that detach from the callus (arrow) and that form a mucilaginous mass (L). Legend: $x \mathrm{xl}=\operatorname{explant~} \mathrm{xylem} ; \mathrm{cc}=$ connecting cells; ep = explant epidermis; $c e=$ connection with explant; $p d=$ protoderm; $p c=$ procambium; $c d=$ scattered cells. Scale: bar A, B and C $=150 \mu \mathrm{m} ; \mathrm{D}, \mathrm{E}, \mathrm{F}, \mathrm{H}, \mathrm{I}, \mathrm{J}, \mathrm{K}$ and $\mathrm{L}=100 \mu \mathrm{m} ; \mathrm{G}=50 \mu \mathrm{m}$. 


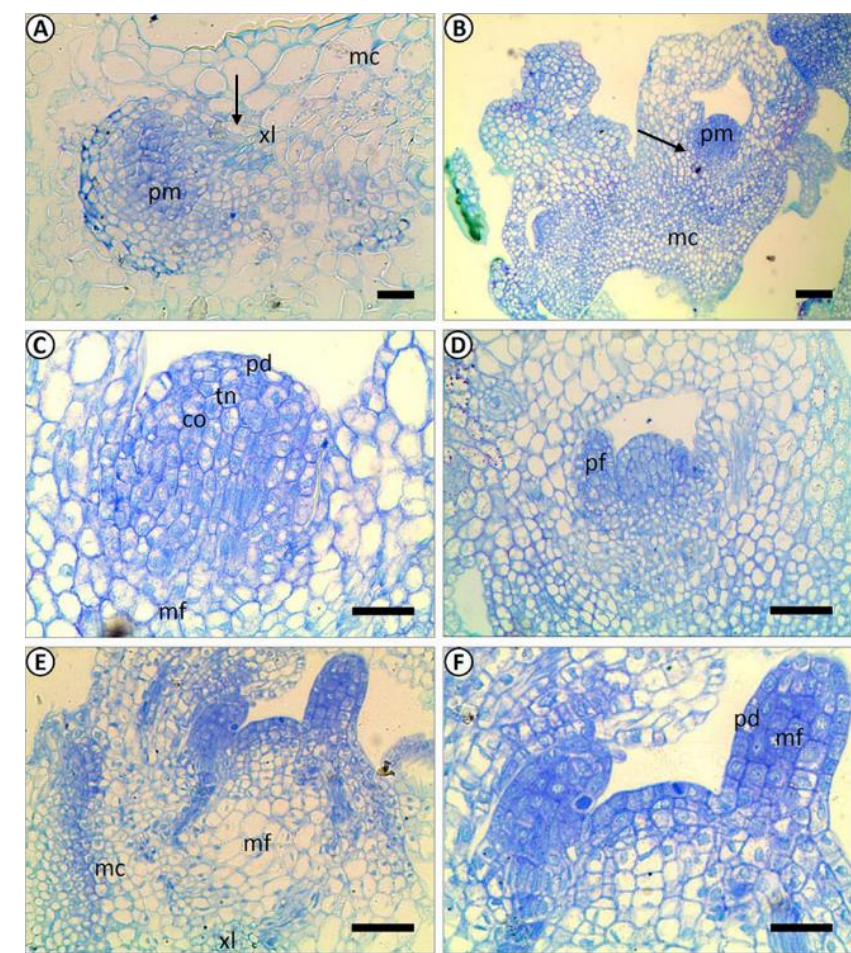

Fig. 6. Light micrograph from sugarcane calli (cultivar RB92579) and bud development by organogenesis. Details of the meristematic regions in the previously regenerable callus of the regeneration conditions $(A)$. The connection to the xylem (arrow) indicates that the callus nourishes the meristematic cells in the absence of a root system. The meristematic point is connected to the callogenic mass (arrow), indicating its origin (A, B). Presence of the tunic (two layers of cells with anticline divisions) and the body (below the tunic, with three layers of cells with periclinal divisions), characteristic of apical meristems (C). Details of the shoots leaf primordia (arrow) with a protoderm and fundamental meristem after seven days of light exposure (D). Details of the structure which nourishes the bud growth through procambium cells fundamental meristem and xylem cells of the callogenic mass (E). After shoots development, leaf primordia alternately arranged (F). After shoots development, leaf primordia alternately arranged $(F)$. Legend: $x l=x y l e m ; ~ p m=$ meristematic point; $m c=$ callogenic mass; $p d=$ protoderm; $t n=$ tunic cells; $c o=$ body cells; $\mathrm{mf}=$ fundamental meristem; $\mathrm{mp}=$ leaf primordium. Scale: $\operatorname{bar} \mathrm{A}, \mathrm{D}$ and $\mathrm{E}=100 \mu \mathrm{m} ; \mathrm{B}=150 \mu \mathrm{m} ; \mathrm{C}$ and $\mathrm{F}=50 \mu \mathrm{m}$.

features of its cultivars (Ho and Vasil, 1983; Rodríguez et al., 1996). Cylindrical, elongated and unconnected cells may characterize nonregenerable calli while structures are nodular with an oval shape been regenerable calli (Na et al., 2007).

There are few published papers relating organogenesis and somatic embryogenesis to sugarcane callus histology (Ho and Vasil, 1983; Dibax et al., 2013; Alcantara et al., 2014; Soares et al., 2014). In most cases, both embryogenic calli and somatic embryos are reported to be achieved with protocols that use the same concentration of 2,4-D (Jahangir et al., 2010; Van Der Vyver et al., 2013; Soares et al., 2014). However, such statements were made subjectively (i.e., without proof of the embryogenic origin of the regenerated material).

Although, in many cases, it is possible to differentiate embryogenic and nonembryogenic calli by physical and visual characteristics alone, these features do not provide complete information about embryo onset (Quiroz-Figueroa et al., 2006). Callus regeneration in a complete plant (whole seedling, including shoots and roots) cannot prove the existence of embryos, since the formation of these organs may be induced either by the addition of growth regulators or by the endogenous level of explant phytohormones (Gopitha et al., 2010).

There are characteristics of developmental stages that precede the formation of an embryo, such as the globular, cordiform, torpedo and cotyledonal stages (Nakamura et al., 1992; Schiavone and Cooke, 1985; Quiroz-Figueroa et al., 2006). According to Zimmerman (1993), the developmental stages of somatic embryogenesis similar to those of zygotic embryogenesis are conceived standard for in vitro culture. Such patterns have not been observed in the present study, as there was no trace of pre-embryogenic structures, such as scutellar, globular and coleoptilar phases, which was typically found in monocotyledons (Schiavone and Cooke, 1985; Nakamura et al., 1992; Quiroz-Figueroa et al., 2006). The zygotic embryos of Paspalum L. (Poaceae) indicate a coleoptile, coleorize, mesocotyl, plumule, scutellum and radicle (Eichemberg and Scatena, 2013). Since these characteristics are regarded as very conserved in Poaceae (Barker et al., 2001), the somatic embryos of sugarcane should maintain the same structural pattern found either in sugarcane seeds or in other plants belonging to this family, which has not been observed in the present study. Both the scutellum and the hood may be less developed provided that

their absorption and protection functions are not often needed under in vitro culture conditions.

\section{Regenerated shoots have organogenic origins}

The formation of meristematic regions in regenerable calli was evident, and was completely enveloped by callogenic mass, leaving no doubt as to its organogenic origin. The evidence of the two layers of cells with anticlinal divisions with three layers of periclinal divisions below characterize the apical meristems. Thus, the growth of the bud nutrition is through procambium cells, by the fundamental meristem and xylem cells of the callogenic mass. This result ponders the relation verified between the xylem and the nutrition meristematic by the callus since there is no root system. 
Neither a root system cell nor tissue linked to the opposite pole of the apical meristem was confirmed any of the sections. Intense rooting of the regenerated shoots was uncovered after a few weeks in regeneration medium without the addition of any substance or growth regulator to the culture medium. Adventitious roots in monocotyledons can usually have an endogenous origin, being formed directly from the shoots, stem or mesocotylus in grasses (Souza and Pereira, 2007). As these roots are detected only after the complete development of the shoots, it is evident that the roots are formed via the development of the embryonic root pole.

Both in vitro organogenesis and the potential for plant regeneration are crucial for sugarcane biotechnology. Hence, we encourage studies on the understanding of molecular and physiological mechanisms underlying the reprogramming of cellular fate during organogenesis. This perspective is important to ensure the quality of the material, favoring the regulation of the cell during organogenesis, a decisive step to acquire new cell types progressively (Tian et al., 2018).

\section{Materials and Methods}

\section{Experiment site and plant material}

For the experiment, we use three sugarcane cultivars (Saccharum spp.): RB855156, RB92579 and RB867515 (provided by the BASF Chemical Company).

\section{Material preparation and disinfestation}

The vegetative shoot apex contains the apical meristem, referred to as the "palm-heart" (Supplementary Figure 4), which has been taken to the laboratory for the following processes. First, the vegetative shoot apex was washed under running water for five minutes for superficial cleaning. Second, in a laminar air flow chamber, the shoot apex was immersed in $70 \%$ ethanol for one minute, followed by a plunge of sodium hypochlorite solution, containing $2 \%$ active chlorine for 20 minutes. Third, excess hypochlorite was removed by triple washing in distilled and autoclaved water to wash away debris from the disinfecting agent. At last, disinfestation was separately performed for each cultivar.

\section{Initial oxidation control and calli induction}

After shoot apex disinfestation, two external leaves were removed to obtain the immature leaf cylinder above the last node (most apical), which was approximately $15 \mathrm{~cm}$ long and $1 \mathrm{~cm}$ in diameter. The explants were cut from the base of the last node to the apex. In an attempt to decrease oxidation, prior to each cut, the scalpel was constantly wet with PVP at $500 \mathrm{ppm}$ and each slice of the explants (1 to 2 $\mathrm{mm}$-thick) was individually inoculated into each tube. A total of 450 explants were inoculated, 150 from each cultivar and 50 from each shoot apex. The tubes were maintained in a growth room at a temperature of $25 \pm 1^{\circ} \mathrm{C}$ in the dark.

The basal medium consists of MS (Murashige and Skoog, 1962) plus $3 \%$ sucrose, $2.3 \mathrm{~g}^{-1} \mathrm{~L}^{-1}$ Phytagel $^{\infty}$ (Sigma) as a gelling agent, $100 \mathrm{mg} \mathrm{L}^{-1}$ polyvinylpyrrolidone (PVP), and 3.0 $\mathrm{mg} \mathrm{L}^{-1} 2,4-\mathrm{D}$. The literature indicates that this is the best concentration for embryogenic callus induction (Soares et al., 2014; Van Der Vyver et al., 2013; Jahangir et al., 2010). The $\mathrm{pH}$ was adjusted to $5.8 \pm 1$, and the culture medium was autoclaved in test tubes with approximately $15 \mathrm{~mL}$ of the aforementioned medium $120 \stackrel{\circ}{\circ}$ for 20 minutes.

\section{Contamination and oxidation evaluation}

The inoculated explants of the three cultivars were also evaluated weekly from the seventh day of inoculation until twenty-eighth day. Contamination was classified as either bacterial or fungal, and the explants were evaluated either for the presence or for the absence of these two contaminants. Thus, the percentage of contamination was calculated from the ratio between the number of contaminated and uncontaminated explants. After each evaluation, the contaminated explants were discarded, making the contamination value for each evaluation be independent of the previous one. To determine the oxidation of the explants, a grading pattern was created to better evaluate the oxidation level over the four weeks: 0 (zero) nonoxidized explant; 1 (one) explant lightly oxidized or exhibiting oxidized parts; and 2 (two) very high or totally oxidized explant.

\section{Calli subcultures and regeneration}

The explants were subcultured every four weeks in sterile, disposable petri dishes, containing $25 \mathrm{~mL}$ of medium (R1 first subculture, R2 - second subculture, R3 - third subculture, and R4 - fourth subculture). The explants were divided into four or five parts and each one gives rise to a plaque. The subcultured materials were maintained in a dark growth room. During subcultures, weekly observations were performed with a magnifying glass, which allows the identification of different types of callus formation.

Calli regeneration by organogenesis was induced in basal MS medium (Martins et al., 2001; Mudry et al., 2013) in a growth room with a 16-hour photoperiod and photon irradiance of $36 \mu \mathrm{mol} \mathrm{m} \mathrm{s}^{-1}$ at $25 \pm 2{ }^{\circ} \mathrm{C}$. To verify the time at which the callus regeneration rate was the highest, a regeneration test was used for each callus type in each subculture. At the end of each subculture, 10 portions of each callus were separated, placed in regeneration medium and classified as a regeneration event.

\section{Anatomical analysis}

Anatomical analyses have been performed under light microscopy. Different callus types maintained in the dark and shoots, previously regenerated, after seven and 15 days under light exposure were fixed in FAA (formaldehyde, acetic acid and $70 \%$ ethanol) for 72 hours and stored in $70 \%$ ethanol for further analysis. The fixed material was subjected to dehydration and then prepared with a Leica Historesin Kit ${ }^{\circ}$. The samples were sectioned, using a rotary microtome and stained with toluidine blue. The sample sections were viewed using a microscope Zeiss Scope A1 connected to a digital camera at a $1024 \times 768$ resolution at different increments. They were analyzed with the aid of the GIMP program (GNU Image Manipulation Program), and scales were positioned with the ImageJ program.

\section{Oxidation rate along the shoot apex}

A new inoculation was performed using calli induction medium with the aim of verifying whether oxidation in the explants was influenced by their position on the shoot apex (basal - apical) or not. Five vegetative shoot apexes from cultivar RB 92579 were inoculated, and the explant position was numbered from 1 to 10 from the shoot apex base to its apex (Supplementary Fig. 6). Oxidation levels were graded as follows: nonoxidized (note 0 ); slightly oxidized (note 1); oxidized (note 2); and very oxidized (note 3 ). 
Different antioxidant agents and their different concentrations were tested. Both ascorbic acid and citric acid used at concentrations of 7.5, 15, 30 and $60 \mathrm{mg} \mathrm{L}^{-1}$ and PVP at 75, 150, 300 and $600 \mathrm{mg} \mathrm{L}^{-1}$ were subjected to microfiltration before their addition to already autoclaved medium.

The control treatment consisted only of wetting the scalpel in a 500 ppm PVP solution prior to the cut of the shoot apex. To other treatments, the solutions employed to wet the scalpel before the cutting were the same, which used antioxidant concentration for each treatment. Five petri dishes with three explants were inoculated for each treatment. The explants were randomly placed in the petri dishes so that each treatment could include both basal and apical explants. The evaluations were realized in every seven days for 42 days.

\section{Experimental design and statistical analysis}

The experimental design was completely randomized, containing 450 explants i.e. 150 explants from each cultivar. Five replicates, containing three explants as an experimental unit, constituted the antioxidant evaluation within six analysis times such as $7 ; 14 ; 21 ; 28 ; 35 ; 42$ days. Ten samples of each callus type constituted the potential regenerative evaluation within three subculture times such as $84 ; 112$; 140 days.

Contamination and oxidation assessments following the first inoculation were performed both by qualitative and by descriptive analysis. Oxidation data of explants were submitted to variance analysis and means compared by Tukey's test $(p \leq 0,05)$. Oxidation along the shoot apex was evaluated through the analysis of variance by using the nonparametric Kruskal-Wallis test $(p \leq 0.05)$, followed by Spearman's rank correlation analysis to examine the relationship between the oxidation of the explants and their position in the stem. The grades obtained in the antioxidant evaluations were subjected to variance analysis, and the means were compared to each other, by using the nonparametric Kruskal-Wallis test in both cases $(p \leq 0.05)$. Regeneration was assessed from the rate of regeneration events for each callus type and at each evaluated time (R1, $R 2, R 3$ and R4).

\section{Conclusions}

Callogenesis of both RB855156 and RB92579 cultivars is efficiently induced using MS medium supplemented with 3.0 $\mathrm{mg} \mathrm{L}^{-1} 2,4-D$. Excess oxidation impairs the formation of regenerable sugarcane calli. The use of antioxidant only in the culture medium is not sufficient to avoid oxidation. However, the use of $7.5 \mathrm{mg} \mathrm{L}^{-1}$ citric acid solution as explant pretreatment is essential to minimize the problem. Both white nodular (BN) and translucent friable (TF) calli have high regenerative potential and they are, therefore, potentially transformable. It is noteworthy mentioning that the mucilaginous callus $(M)$ does not regenerate. There are structural differences between the calluses $B N, T F$ and $M$, the callus $\mathrm{BN}$ being the most complex in relation to the organization of tissues and cell types. BN and TF callus sprouts of the RB92579 cultivar are of organogenic origin, confirmed by histological analysis. The concentration of 2,4$D$ used is efficient in the induction of callogenesis in two of the three cultivars analyzed, and the severe oxidation of the explants impairs the regeneration of the calli attained. Among the three types of calli accomplished from the
RB92579 and RB855156 cultivars, two of them reveal a regenerative capacity and they are of organogenic origin, as sustained by histological analysis.

\section{Contributions and conflict of interests}

The authors declare no conflict of interest. All authors contributed to the study conception and design. The first [Manoel Viana Linhares-Neto] and second [Letícia Rios Vieira] authors both contributed equally.

\section{Acknowledgements}

The authors thank the research funding agencies: CNPq (The Brazilian National Council for Scientific and Technological Development that is an organization of the Brazilian federal government under the Ministry of Science and Technology) and CAPES (Brazilian federal government agency under the Ministry of Education, responsible for quality assurance in postgraduate institutions in Brazil). Moreover, they also thank prof. Dr. Norma Lírio de Leão Joseph for English review.

\section{References}

Alcantara GB, Dibax R, Oliveira RA, Bespalhok-Filho JC, Daros E (2014) Plant regeneration and histological study of the somatic embryogenesis of sugarcane (Saccharum spp.) cultivars RB855156 and RB72454. Acta Scientiarum Agronomy. 36:63-72.

Andrade JSO, Oliveira FJ, Anunciação-Filho CJ, Melo LJ, Reis OV (2011) Progenies evaluation in RB families in the initial stage of genetic improvement in sugarcane. Revista Brasileira de Ciências Agrárias. 6:609-616.

Appezato-da-Glória B, Hayashi AH (2012) Anatomia dos órgãos vegetais: Raiz. In Anatomia Vegetal $3 \mathrm{Ed}$, Eds. Appezzato-da-Glória B, Carmello-Guerreiro SM, vol 1. UFV, Viçosa.

Attia OA, Mohamed AM, Hafez MA, Sadik AS, Abdelallah NA (2005) Establishment of regeneration and transformation systems of F144 sugarcane cultivar. Pak J Biotechnol. 2:1518.

Barker NP, Clark, LG, Davis JI, Duvall M.R, Guala GF, Hsiao C, Kellogg EA, Linder HP, Mason-Gamer RJ, Mathews SY, Simmons MP, Soreng RJ, Spangler RE (2001) Phylogeny and subfamilial classification of the grasses (Poaceae). Annals of the Missouri Botanical Garden. 88:373-457.

Basnayake SWV, Moyle R, Birch RG (2011) Embryogenic callus proliferation and regeneration conditions for genetic transformation of diverse sugarcane cultivars. Plant Cell Reports. 30:439-448.

Bassan JS, Reiniger LRS, Rocha BHG, Severo CRP, Flores AV (2006) Oxidação fenólica, tipo de explante e meios de cultura no estabelecimento in vitro de canafístula (Peltophorum dubium (Spreng.) Taub.). Ciência Florestal. 16:381-390.

Birch RG (1997) Plant transformation: Problems and strategies for practical application. Annual Review of Plant Physiology and Plant Molecular Biology. 48:297-326.

Borneman Z, Gökmen V, Nijhuis HH (2001) Selective removal of polyphenols and brown colour in apple juices using PES/PVP membranes in a single ultrafiltration process. Separation and Purification Technology. 22:53-61. 
Brondani DJ (2003) Síntese e avaliação da atividade antimicrobiana de análogos da primina 5 e 6 alquilsubstituídos. Acta Farmacéutica Bonaerense. 22:217-222.

Camolesi MR, Kaihara ES, Saconi CG, Faria RTd, Neves CSVJ (2007) Redução da oxidação na propagação in vitro da bananeira 'maçã'. Ciência e Agrotecnologia. 31:1237-1241.

Carvalho SAD, Furtado AT (2013) O melhoramento genético de cana-de-açúcar no Brasil e o desafio das mudanças climáticas globais. Revista Gestão \& Conexões. 2:22-46.

Cidade DAP, Oliveira Garcia R, Duarte AC, Sachetto-Martins G, Mansur E (2006) Morfogênese in vitro de variedades brasileiras de cana-de-açúcar. Pesquisa Agropecuária Brasileira. 41:385-391.

Davey MR, Anthony P, Patel D, Power JB (2010) Plant protoplasts: isolation, culture and plant regeneration. In: Plant cell culture essential methods, vol 1. Wiley-Blackwell, New York, 1:153-173.

De Klerk GJ, Arnholdt-Schmitt B, Lieberei R, Neumann KH (1997) Regeneration of roots, shoots and embryos: Physiological, biochemical and molecular aspects. Biologia Plantarum. 39:53-66.

Dhaliwal HS, Ramesar-Fortner NS, Yeung EC, Thorpe TA (2003) Competence, determination, and meristemoid plasticity in tobacco organogenesis in vitro. Canadian Journal of Botany. 81:611-621.

Dibax R, Alcantara GB, Machado MP, Filho JCB, Oliveira RA (2013) Protocol optimization and histological analysis of in vitro plant regeneration of RB92579 and RB93509 sugarcane cultivars. Ciência Rural. 43:49-54.

Duclercq J, Sangwan-Norreel B, Catterou M, Sangwan RS (2011) De novo shoot organogenesis: From art to science. Trends in Plant Science. 16:597-606.

Eichemberg MT, Scatena VL (2013) Morphology and anatomy of the diaspores and seedling of Paspalum (Poaceae, Poales). Anais da Academia Brasileira de Ciências. 85:1389-1396.

Evert RF (2006) Esau's plant anatomy: meristems, cells, and tissues of the plant body: their structure, function, and development, vol 1. John Wiley \& Sons.

Garcia, FR., Cavalcante, FLDS., Souza, RAD., Houllou, LM. (2019). Kasugamycin on Leifsonia xyli subsp. xyli in the in vitro culture of sugarcane. Ciência Rural. 49(8).

Gopitha K, Bhavani AL, Senthilmanickam J (2010) Effect of the different auxins and cytokinins in callus induction, shoot, root regeneration in sugarcane. Int J Pharma Bio Sci. 1:975-6299.

He Q, Luo Y (2007) Enzymatic browning and its control in fresh-cut produce. Stewart Postharvest Review. 3:1-7.

Hirano SS, Upper CD (1990) Population biology and epidemiology of Pseudomonas syringae. Annual Review of Phytopathology 28:155-177.

Ho WJ, Vasil IK (1983) Somatic embryogenesis in sugarcane (Saccharum officinarum L.). The morphology and physiology of callus formation and the ontogeny of somatic embryos. Protoplasma. 118:169-180.

Houllou LM, Souza RA (2015) Protocol optimization for in vitro sugarcane establishment from stem cuttings shoot tips. Research in Biotechnology. 6:4, 42-48.

Jahangir GZ, Nasir IA, Sial RA, Javid MA, Husnain T (2010) Various hormonal supplementations activate sugarcane regeneration in-vitro. Journal of Agricultural Science. 2:231-231

Jimtha JC, Smitha PV, Anisha C, Deepthi T, Meekha G, Radhakrishnan EK, Gayatri GP, Remakanthan A (2014) Isolation of endophytic bacteria from embryogenic suspension culture of banana and assessment of their plant growth promoting properties. Plant Cell, Tissue and Organ Culture (PCTOC). 118:57-66.

Kakani A, Li G, Peng Z (2009) Role of aux1 in the control of organ identity during in vitro organogenesis and in mediating tissue specific auxin and cytokinin interaction in Arabidopsis. Planta. 229:645-657.

Lal M, Tiwari AK, Gupta GN (2015) Commercial Scale Micropropagation of Sugarcane: Constraints and Remedies. Sugar Tech. 17: 339-347.

Lee M, Phillips RL (1988) The chromosomal basis of somaclonal variation. Annual Review of Plant Physiology and Plant Molecular Biology. 39:413-437.

Leifert C, Ritchie JY, Waites WM (1991) Contaminants of plant-tissue and cell cultures. World Journal of Microbiology and Biotechnology. 7:452-469.

Maciel SDA, Fermino-Junior PCP, Silva RAd, ScherwinskiPereira JE (2010) Morpho-anatomical characterization of embryogenic calluses from immature zygotic embryo of peach palm during somatic embryogenesis. Acta Scientiarum Agronomy. 32:263-267.

Malabadi RB, Mulgund GS, Mulgund GS, Nataraja K, Nataraja K, Kumar SV, Kumar SV (2011) Induction of somatic embryogenesis in different varieties of sugarcane (Saccharam officinarum L.). Research in Plant Biology. 1:39-48.

Mancini MC, Cardoso-Silva CB, Costa EA, Marconi TG, Garcia AAF, Souza AP. (2017) New developments in sugarcane genetics and genomics. In Advances of basic science for second generation bioethanol from sugarcane, 159-174. 159-174p.

Martins GS, Mansur E (2001) Morfogênese in vitro e susceptibilidade de calos de variedades nacionais de canade-açúcar (Saccharum officinarum L.) a agentes seletivos utilizados em sistemas de transformação genética. Brazilian Journal of Botany. 24:73-77.

Melo B, Pinto J, Luz JMQ, Peixoto JR, Juliatti FC (2001) Diferentes antioxidantes no controle da oxidação, germinação e desenvolvimento das plântulas na cultura in vitro de embriões da guarirobeira [Syagrus oleracea (Mart.) Becc.]. Ciência e Agrotecnologia. 25:1301-1306.

Mudry CS, Souza DKK, Dibax R, Alcântara GB, BespalhokFilho JC (2013) Embriogênese somática da cultivar RB966928 e do clone RB986419 de cana-de-açúcar (Saccharum spp.). Semina: Ciências Agrárias. 34:10231032.

Murashige T, Skoog F (1962) A revised medium for rapid growth and bio-assays with tobacco tissue cultures. Physiologia Plantarum. 15:473-497.

Na H, Kim KW, Kwack Y, Kim SK, Chun C (2007) Comparative anatomy of embryogenic and non-embryogenic calli Frompimpinella brachycarpa. Journal of Plant Biology. 50:344-350.

Nagata T (1994) Genes involved in the dedifferentiation of plant cells. Int J Dev Biol. 38:321-327.

Nakamura T, Taniguchi T, Maeda E (1992) Studies on somatic embryogenesis of coffee by scanning electron microscope. Japanese Journal of Crop Science. 61:476-486.

Nawaz M, Ullah I, Iqbal N, Iqbal MZ, Javed MA (2014) Improving in vitro leaf disk regeneration system of sugarcane (Saccharum officinarum L.) with concurrent shoot/root induction from somatic embryos. Turkish Journal of Biology. 37:6. 
Niedz RP, Evens TJ (2007) Regulating plant tissue growth by mineral nutrition. In Vitro Cellular \& Developmental Biology-Plant. 43:370-381.

North J, Ndakidemi P, Laubscher C (2010) The potential of developing an in vitro method for propagating strelitziaceae. African Journal of Biotechnology. 9:75837588.

Orlikowska T, Nowak K, Reed B (2017) Bacteria in the plant tissue culture environment. Plant Cell, Tissue and Organ Culture (PCTOC). 128:487-508.

Oropeza M, Guevara P, García Ed, Ramírez JL (1995) Identification of somaclonal variants of sugarcane (Saccharum spp.) resistant to sugarcane mosaic virus via rapd markers. Plant Molecular Biology Reporter. 13:182191.

Palú EG, Corrêa LdS, Suzuki AN, Boliani AC (2011a) Use of antibiotics for the control of endogenous bacteria aiming the micropropagation of fig trees. Revista Brasileira de Fruticultura. 33:587-592.

Palú EG, Corrêa LdS, Suzuki AN, Boliani AC (2011b) Uso de antibióticos para o controle de bactérias endógenas visando à micropropagação da figueira. Revista Brasileira de Fruticultura. 33:587-592.

Pernisová M, Klíma P, Horák J, Válková M, Malbeck J, Souček P, Reichman P, Hoyerová K, Dubová J, Friml J (2009) Cytokinins modulate auxin-induced organogenesis in plants via regulation of the auxin efflux. Proceedings of the National Academy of Sciences. 106:3609-3614.

Quiroz-Figueroa FR, Rojas-Herrera R, Galaz-Avalos RM, Loyola-Vargas VM (2006) Embryo production through somatic embryogenesis can be used to study cell differentiation in plants. Plant Cell, Tissue and Organ Culture. 86:285.

Ramage CM, Williams RR (2002) Mineral nutrition and plant morphogenesis. In Vitro Cellular \& Developmental BiologyPlant. 38:116-124.

Raza S, Qamarunisa S, Hussain M, Jamil I, Anjum S, Azhar A, Qureshi JA (2012) Regeneration in sugarcane via somatic embryogenesis and genomic instability in regenerated plants. Journal of Crop Science and Biotechnology. 15:131136.

Reddy MC, Bramhachari P, Murthy KSR (2015) Optimized plant tissue culture protocol for in vitro morphogenesis of an endangered medicinal herb Ceropegia ensifolia Bedd. Tropical and Subtropical Agroecosystems. 18:95-101.

Rodríguez S, Mondéjar C, Ramos ME, Díaz E, Maribona R, Ancheta O (1996) Sugarcane somatic embryogenesis: A scanning electron microscopy study. Tissue and Cell. 28:149-154.

Sangwan RS, Sangwan-Norreel BS, Harada H (1997) In vitro techniques and plant morphogenesis. Plant Biotechnology. 14:93-100.

Santosa DA, Hendroko R, Farouk A, Greiner R (2004) A rapid and highly efficient method for transformation of sugarcane callus. Molecular Biotechnology. 28:113-119.
Sartor FR, Zanotti RF, Pôssa KF, Pilon AM, Fukushima $\mathrm{CH}$ (2013) Diferentes meios de cultura e antioxidantes no estabelecimento in vitro do jacarandá da bahia. Bioscience Journal. 29.

Schiavone FM, Cooke TJ (1985) A geometric analysis of somatic embryo formation in carrot cell cultures. Canadian Journal of Botany. 63:1573-1578.

Silva MA, Gonçalves PS (2011) Inbreeding in sugarcane varieties. Ciência Rural. 41:580-586.

Soares RR, Melo EF, Melo CG, Rodrigues CR, Vieira MS, Barbosa MHP (2014) The use of histological analysis for the detection of somatic embryos in sugarcane. African Journal of Biotecnology. 13:762-767.

Souza AV, Pereira AMS (2007) Enraizamento de plantas cultivadas in vitro. Revista Brasileira de Plantas Medicinais. 9:103-116.

Tian X, Zhang C, Xu J (2018) Control of cell fate reprogramming towards de novo shoot organogenesis. Plant and Cell Physiology. 59:4, 713-719.

Van Der Vyver C, Conradie T, Kossmann J, Lloyd J (2013) In vitro selection of transgenic sugarcane callus utilizing a plant gene encoding a mutant form of acetolactate synthase. In Vitro Cellular \& Developmental Biology Plant. 49:198-206.

Werner ET, Cuzzuol GRF, Pessotti KV, Lopes FP, Roger JA (2009) Controle da calogênese do Pau-Brasil in vitro. Revista Árvore. 33:987-996.

Zamir R, Khalil SA, Shah ST, Khan MS, Ahmad K, Shahenshah Ahmad $N$ (2012) Efficient in vitro regeneration of sugarcane (Saccharum officinarum L.) from bud explants. Biotechnology \& Biotechnological Equipment. 26 (4):30943099.

Zimmerman JL (1993) Somatic embryogenesis: A model for early development in higher plants. The Plant Cell. 5:14111423. 